\title{
Порівняльне дослідження трансабдомінальної і ретроперитонеальної лапароскопічної адреналектомії
}

\author{
В. В. Грубнік, Р. С. Парфентьев, В. В. Ільяшенко, О. С. Бурлак \\ Одеський національний медичний університет
}

\section{Comparative investigation of transabdominal and retroperitoneal laparoscopic adrenalectomy}

\author{
V. V. Grubnik, R. S. Parfentiev, V. V. Ilyashenko, O. S. Burlak \\ Odessa National Medical University
}

\begin{abstract}
Реферат
Мета. Порівняти результати й ефективність ретроперитонеальної і трансабдомінальної лапароскопічної андреналектомії з визначенням показань до їх застосування.

Матеріали і методи. Дослідження виконане на базі Одеської обласної клінічної лікарні. Обстежено 78 пацієнтів, яким виконали трансабдомінальну $(\mathrm{n}=44)$ або ретроперитонеальну $(\mathrm{n}=34)$ лапароскопічну адреналектомію.

Результати. Показано, що задній ретроперитонеальний доступ має значні переваги над трансабдомінальним доступом у разі виконання лапароскопічної адреналектомії: істотне скорочення тривалості та зниження травматичності операції, зменшення крововтрати, больового синдрому, отримання хорошого косметичного результату, скорочення строків перебування пацієнтів у стаціонарі.

Висновки. Задній ретроперитонеальний доступ є методом вибору у хворих, яким раніше були виконані оперативні втручання на органах черевної порожнини.

Ключові слова: трансабдомінальний доступ; ретроперитонеальний доступ; лапароскопічна адреналектомія.

Abstract

Objective. To compare the results and efficacy of retroperitoneal and transabdominal laparoscopic adrenalectomy with determination of indications to its application.

Materials and methods. The investigation was performed on the base of Odessa Regional Clinical Hospital. There were examined 78 patients, in whom transabdominal $(n=44)$ or retroperitoneal $(n=34)$ laparoscopic adrenalectomy were conducted. Results. There was shown, that posterior retroperitoneal access owes significant advantages over transabdominal access while performance of laparoscopic adrenalectomy the essential shortening of the operation duration and the traumaticity lowering, the blood loss and the pain syndrome reduction, obtaining of good cosmetic result, the patients' stationary stay shortening. Conclusion. Posterior retroperitoneal access constitutes the method of choice for the patients, previously operated on abdominal organs.

Keywords: transabdominal access; retroperitoneal access; laparoscopic adrenalectomy.
\end{abstract}

Пухлини наднирників діагностують у 0,2 - 10\% населення [1]. У 1992 р. американський хірург M. Gagner виконав першу лапароскопічну адреналектомію [2]. 3 того часу методика стала «золотим стандартом» у лікуванні невеликих пухлин надниркових залоз (Н3). Як правило, переважна більшість хірургів використовує трансабдомінальний лапароскопічний доступ для видалення як правого, так і лівого наднирника з положенням хворого на операційному столі - лежачи на боку відповідно до локалізації пухлини [3, 4]. Трансабдомінальна лапароскопічна адреналектомія (ТЛА) не завжди є простою в технічному плані операцією, особливо коли видаляють лівий наднирник. Тому німецький хірург M. К. Walz запропонував використовувати задній ретроперитонеальний лапароскопічний доступ з положенням хворого на операційному столі - лежачи на животі [5]. 3 огляду на відносно невелику кількість спостережень суттевих переваг ретроперитонеального доступу не виявлено [3, 6]. Водночас не виключено, що у разі збільшення кількості спостережень будуть знайдені більш переконливі докази переваг ретроперитонеальної лапароскопічної адреналектомії (РЛА).

Мета дослідження: порівняти результати й ефективність РЛА та ТЛА з визначенням показань до їх застосування.

\section{Матеріали і методи дослідження}

У клініці Одеського національного медичного університету ТЛА почали виконувати з 1995 р. 32005 р. нами впроваджена методика задньої ретроперитонеальної адреналектоміі (ЗРЛА). Дане дослідження проведено щодо 78 хворих, оперованих за період з 2008 по 2015 р. Ми навмисно не включили в дане дослідження перші 20 ТЛА, оскільки ці операції розглядали як етап освоєння нової методики.

Серед оперованих хворих переважали жінки - 59, чоловіків було 19. Вік хворих - від 29 до 68 років. У 62 пацієнтів виявлені гормонально-активні пухлини Н3: у 25 - феохромоцитома, у 20 - альдостерома, у 17 - кортикостерома. Ці хворі перебували під наглядом, лікування їм проводили ендокринологи з неодноразовим дослідженням кро- 
ві і сечі на визначення активності гормонів наднирників (альдостерон-ренінового співвідношення, метанефринів, кортизолу). У 16 пацієнтів пухлини НЗ були гормонально-неактивними (інціденталоми) та виявлені під час виконання ультразвукового дослідження (УЗД), комп’ютерної томографії (КТ) і магнітно-резонансної томографії.

Розмір пухлин НЗ коливався від 1,7 до 10,5 см, у середньому становив $(4,2 \pm 2,3)$ см. Індекс маси тіла (IMT) оперованих пацієнтів був у межах від 24,2 до 50,2 кг / м $^{2}$

У 44 пацієнтів (1-ша група) виконали ТЛА, у 34 (2-га група) - ЗРЛА. Істотних відмінностей між двома групами хворих, оперованих за методиками ТЛА і ЗРЛА, не було (табл. 1). Важливо зазначити, що у 2-й групі 13 пацієнтам раніше були виконані різні оперативні втручання, у тому числі у 5 - верхньосерединна лапаротомія з операціями на шлунку, підшлунковій залозі, товстій кишці, що стало протипоказанням до виконання ТЛА.

Техніка ТЛА була такою [2]. Використовували, як правило, чотири троакари. Виконуючи правобічну адреналектомію, виділяли й обов'язково кліпували центральну вену наднирника. Решту судин виділяли, коагулювали і перетинали за допомогою апарата LigaSure (фірма Covidien) або застосовували вдосконалену біполярну коагуляцію (коагулятор Martin, Німеччина). Більш складним було виконання лівосторонньої адреналектомії. Для виділення НЗ доводилося мобілізовувати селезінковий кут товстої кишки,

\begin{tabular}{|c|c|c|c|}
\hline \multirow{3}{*}{$\begin{array}{r}\text { Таблиця } 1 . \\
\text { Показники }\end{array}$} & $\begin{array}{l}\text { ристика оп } \\
\text { нами Н3 }\end{array}$ & ваних хвор & \multirow[b]{3}{*}{$\mathrm{p}$} \\
\hline & \multicolumn{2}{|c|}{ Група хворих } & \\
\hline & $\begin{array}{c}\text { 1-ша, ТЛА } \\
(\mathrm{n}=44)\end{array}$ & 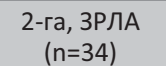 & \\
\hline \multicolumn{4}{|l|}{ Стать } \\
\hline чоловіки & 10 & 9 & $>0,05$ \\
\hline жінки & 34 & 25 & $>0,05$ \\
\hline Вік, роки & $\begin{array}{c}42,6 \\
(32-64)\end{array}$ & $\begin{array}{c}45,8 \\
(29-68)\end{array}$ & $>0,05$ \\
\hline $\mathrm{IMT}, \mathrm{kr} / \mathrm{M}^{2}$ & $\begin{array}{c}29,4 \\
(25,6-50,2)\end{array}$ & $\begin{array}{c}28,2 \\
(24,2-46,8)\end{array}$ & $>0,05$ \\
\hline \multicolumn{4}{|l|}{ Локалізація пухлини } \\
\hline справа & 25 & 18 & $=0,05$ \\
\hline зліва & 19 & 16 & $=0,05$ \\
\hline \multicolumn{4}{|l|}{ Вид пухлини } \\
\hline феохромоцитома & 13 & 12 & $>0,05$ \\
\hline альдостерома & 10 & 8 & $>0,05$ \\
\hline кортикостерома & 5 & 4 & $>0,05$ \\
\hline інціденталома & 16 & 10 & $>0,05$ \\
\hline Розмір пухлини, см & $\begin{array}{c}3,9 \\
(1,7-8,5)\end{array}$ & $\begin{array}{c}4,2 \\
(1,8-10)\end{array}$ & $>0,05$ \\
\hline \multicolumn{4}{|l|}{$\begin{array}{l}\text { Раніше виконані } \\
\text { оперативні втручання }\end{array}$} \\
\hline $\begin{array}{l}\text { верхня серединна } \\
\text { лапаротомія }\end{array}$ & 1 & 5 & $>0,05$ \\
\hline $\begin{array}{l}\text { нижня серединна } \\
\text { лапаротомія }\end{array}$ & 2 & 3 & $>0,05$ \\
\hline $\begin{array}{l}\text { лапароскопічна } \\
\text { холецистектомія }\end{array}$ & 3 & 5 & $>0,05$ \\
\hline
\end{tabular}

хвіст підшлункової залози і зв'язки селезінки. Центральну вену лівого наднирника виділяли і у ряду хворих кліпували, однак найчастіше коагулювали за допомогою аппарата LigaSure і перетинали.

Коли виконували ЗРЛА за методикою M. K. Walz, положення хворого на операційному столі було лежачи на животі [5]. Використовували всього три троакари: один 10міліметровий - для ендоскопа і два 5-міліметрових - для інструментів. У заочеревинну клітковину вводили вуглекислий газ під тиском 20 - 25 мм рт. ст., створюючи в такий спосіб робочий простір. Знаходили і видаляли наднирник з навколишньою клітковиною. Судини коагулювали апаратом LigaSure. Виділивши центральну вену справа, як правило, накладали на неї кліпсу і тільки після цього перетинали за допомогою апарата Liga Sure. Віддалений наднирник поміщали в спеціальний контейнер і видаляли через 10-міліметровий троакарний порт. Дренаж ставили тільки у разі невеликої кровотечі з навколишніх тканин. Необхідно зазначити, що під час виконання ЗРЛА дренаж використовували тільки у 5 з 34 хворих, ТЛА - у 38 з 44 хворих.

Результати оцінювали за такими критеріями: тривалість оперативного втручання, об'єм крововтрати, число інтра - і післяопераційних ускладнень, вираженість післяопераційного болю, нудоти, блювання, строки першого прийому їжі, тривалість перебування у стаціонаpi. Вираженість больового синдрому визначали в балах за візуально-аналоговою шкалою (ВАШ) [7] через 4, 12, 24 і 36 год після операції. Спостерігали виражений біль в області плеча і надпліччя. Контролювали також потребу в аналгетиках: опіоїдах або нестероїдних протизапальних засобах (НПЗ3).

У хворих з гормонально-активними пухлинами проводили ретельний моніторинг артеріального тиску (АТ) під час операції і в післяопераційному періоді, ці хворі після операції перебували під ретельним наглядом не тільки хірургів, які оперували, а й лікарів-ендокринологів, їм через 1, 12, 24 та 48 міс визначали активність гормонів НЗ. Обов'язково виконували повторні контрольні дослідження - УЗД і КТ. Фіксували виникнення гриж у місці установки троакарів.

Всі отримані дані статистично опрацьовували, використовуючи параметричні та непараметричні методи з визначенням критеріїв $\chi^{2}$ і Ст'юдента. Статистичний аналіз проводили за допомогою комп'ютерної програми Statistica 10.

\section{Результати}

Усі операції виконані успішно без серйозних ускладнень і смертності (табл. 2). Тривалість операцій була статистично достовірно коротшою у хворих, яким виконували ЗРЛА ( $<$ 0,05), найбільш виражено різнилася тривалість операції у разі виконання лівосторонньої адреналектомії: ТЛА - $(108 \pm 29,5)$ хв, ЗРЛА - $(62 \pm 16,8)$ хв (р $<0,01)$. Об'єм інтраопераційної крововтрати також був менший у разі виконання ЗРЛА - $(60,8 \pm 18)$ мл, тоді як у 
разі виконання ТЛА він становив $(112 \pm 30)$ мл $(\mathrm{p}<0,05)$.

Вираженість больового синдрому була значно меншою через 4, 12, 24 год після виконання ЗРЛА (p < 0,01). Цим пацієнтам призначали після операції також достовірно менше аналгетиків ( $<$ < 0,01). Жодному хворому після ЗРЛА не призначали опіоїдних препаратів, тоді як після ТЛА 28 із 44 хворих отримували аналгетики. На біль в області плеча скаржилися також тільки хворі після ТЛА. АТ знизився або нормалізувався практично у всіх пацієнтів, яким видалили гормонально-активні пухлини НЗ.

Перший прийом їжі був можливий уже через 4 - 6 год після ЗРЛА і тільки через 12 - 24 год після ТЛА (p <0,05). Після ЗРЛА вже через 4 - 6 год хворі підводилися і починали ходити, не відчуваючи болю в області живота, випорожнення у них нормалізувалися практично в першу добу після операції. Тривалість перебування у стаціонарі цих хворих була достовірно коротше, ніж хворих після ТЛА - відповідно 4,1 та 7,2 ліжко-дня ( $<$ 0,05). Частота конверсії була так само вища у разі виконання ТЛА. У однієї хворої вдалися до конверсії через виражений спайковий процес після раніше виконаної верхньосерединної лапаротоміі. У 2 інших хворих конверсія була обумовлена пошкодженням селезінки і вираженою кровотечею з ниркової вени через прорізання кліпсою стінки основної вени лівого наднирника. Всього одну конверсію через великі розміри пухлини, діаметр якої сягав 10,5 см, застосували під час виконання ЗРЛА справа.

Післяопераційне ускладнення у вигляді гематоми в області видаленої НЗ виникло у 1 хворого після ЗРЛА. Після ТЛА спостерігали ускладнення у 3 хворих: травматичний панкреатит через пошкодження хвоста підшлункової залози під час виконання операції зліва (1), утворення гематоми (1) і плеврит (1).

Спостерігаючи за хворими у віддалені строки після операції, ми не виявили неповного видалення пухлин НЗ у жодного хворого. Моніторинг рівнів гормонів наднирників показав, що у переважної більшості пацієнтів з гормонально-активними пухлинами у віддалені строки після операції вони або нормалізувались, або достовірно знизились. АТ нормалізувався у 39 із 48 хворих. Лікарські засоби для зниження АТ продовжували приймати після операції 15 пацієнтів. Слід підкреслити, що після адреналектомії навіть невеликі дози антигіпертензійних препаратів були досить ефективними.

\section{Обговорення}

У даний час практично всі хірурги визнали переваги лапароскопічних методик виконання адреналектомії, оскільки вони значно менш травматичні, ніж відкриті операції [2 - 6]. Чи є ретроперитонеальні лапароскопічні втручання менш травматичними, ніж трансабдомінальні, до кінця не з'ясовано. У трьох проспективних дослідженнях було порівняно ретроперитонеальні і трансабдомінальні лапароскопічні адреналектомії, значних відмінностей не виявлено [3]. У той же час дані, отримані польськими хірургами, свідчать про значні переваги ретроперитонеально-

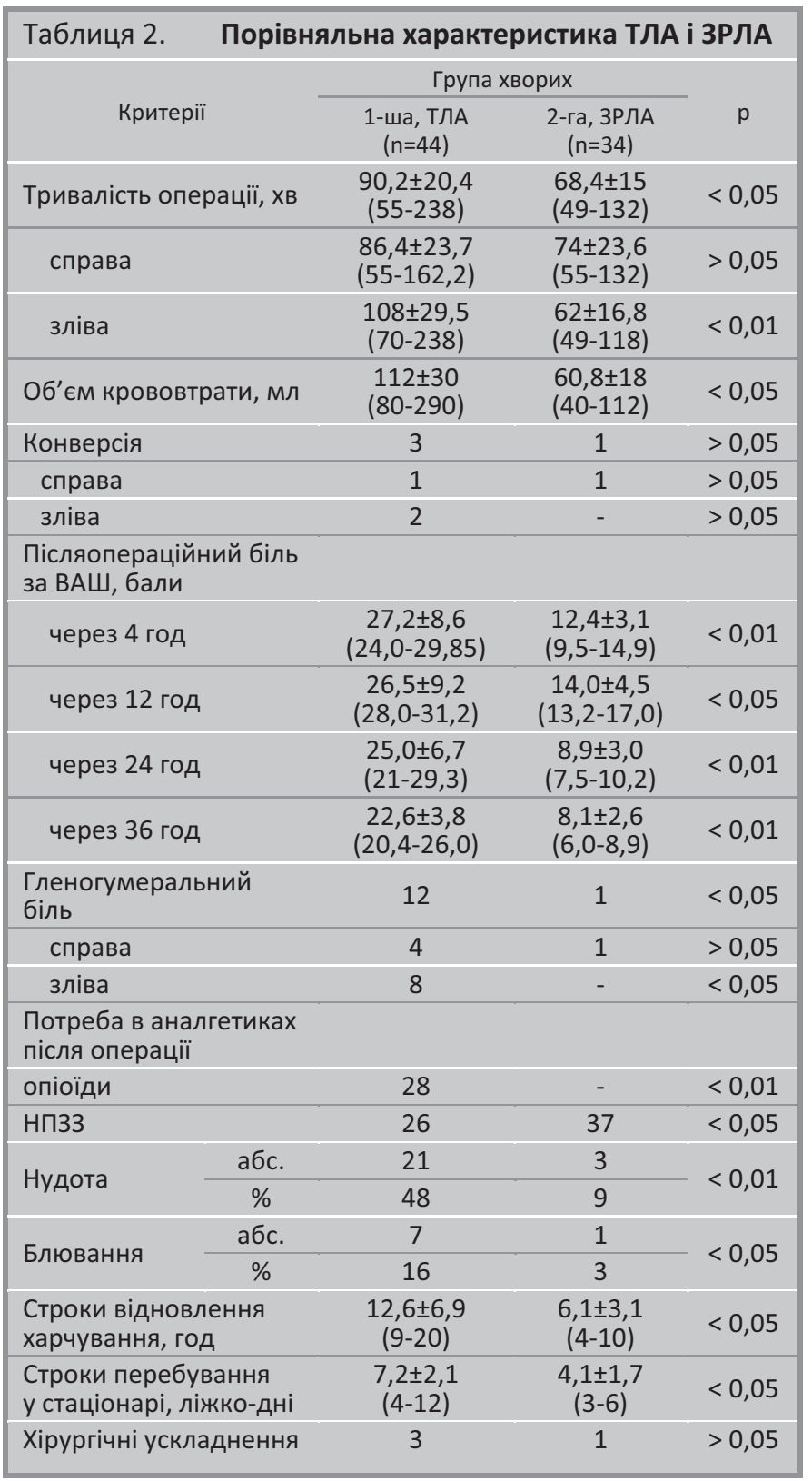

го доступу [6]. Ми також отримали досить переконливі дані про серйозні переваги ретроперитонеального доступу. Оскільки хірург не витрачає часу на дисекцію і доступ до заочеревинного простору, тривалість ЗРЛА достовірно менше, ніж ТЛА ( $<<0,05)$, особливо це стосується лівосторонньої адреналектомії ( $<$ 0,01). Больовий синдром значно менший у разі використання заднього ретроперитонеального доступу, тому що не травмуються внутрішньочеревні органи і очеревина.

На нашу думку, задній ретроперитонеальний доступ $є$ методом вибору у пацієнтів, яким раніше виконали лапаротомне втручання. У всіх 5 пацієнтів, яким раніше виконали верхньосерединну лапаротомію, нам вдалося без особливих зусиль видалити пухлину НЗ через задній доступ, тоді як під час виконання ТЛА раніше виконана лапаротомія стала причиною конверсії. 
Звичайно, залишається відкритим питання, за яких розмірів пухлин можна виконати ЗРЛА. За даними провідних хірургів, задній ретроперитонеальний доступ показаний за наявності пухлин маленького і середнього розміру до 5 - 6 см [5, 7]. Водночас удосконалення хірургічної техніки давало нам можливість видаляти пухлини розмірами 8 - 9 см.

Треба визнати, що задній ретроперитонеальний доступ трохи складніший для хірурга, який оперує, ніж трансабдомінальне втручання, оскільки він не бачить відразу основних анатомічних орієнтирів. Тому для освоєння даної техніки лапароскопічних втручань потрібно пройти навчання у спеціалізованих центрах і взяти участь у виконанні як мінімум 20 операцій [5, 6].

\section{Висновки}

1. Задній ретроперитонеальний доступ має значні переваги над трансабдомінальним доступом під час виконання лапароскопічної адреналектомії, оскільки дає змогу істотно скоротити тривалість операції, знизити ії травматичність, зменшити об'єм крововтрати, больовий синдром, отримати хороший косметичний результат і скоротити строки перебування пацієнтів у стаціонарі.

2. Задній ретроперитонеальний доступ є методом вибору у пацієнтів, яким раніше були виконані оперативні втручання на органах черевної порожнини.

\section{Підтвердження}

Фінансування. Власні кошти.

\section{Інформація про внесок кожного учасника}

Грубнік В. В. - концепція і дизайн дослідження, аналіз отриманих даних, формування висновків; Парфентьєв P. С. - збір та опрацювання матеріалів, аналіз отриманих даних, написання тексту, оформлення до друку; Ільяшенко В. В. - збір та опрацювання матеріалів, аналіз отриманих даних; Бурлак О. С. - збір та опрацювання матеріалів, оформлення до друку. Всі автори прочитали і схвалили остаточний варіант рукопису.

\section{Конфлікт інтересів}

Автори, які взяли участь в цьому дослідженні, декларують відсутність конфлікту інтересів щодо цього рукопису.

Згода на публікацію

Всі автори дали згоду на публікацію цього рукопису.

\section{References}

1. Cherenko SM, Larin OS, Tovkay OA. Two sides of the establishment of above-the-street plots. Klinichna endokrinologiya ta endokrinna khirhiya. 2013;(1);62-70. doi:10.24026/1818-1384.1(42).2013.77469.

2. Gagner M, Lacroix A, Bolte E, Pomp A. Laparoscopic adrenalectomy. The importance of a flank approach in the lateral decubitus position. Surg Endosc. 1994; 8(2):135-8. PMID: 8165486.

3. Gagner M, Pomp A, Heniford BT, Pharand D, Lacroix A. Laparoscopic adrenalectomy: lessons learned from 100 consecutive procedures. Ann Surg. 1997; 226(3):238-46. doi: 10.1097/00000658-199709000-00003.

4. Lezoche E, Guerrieri M, Crosta F, Paganini A, D’Ambrosio G, Lezoche G, et al. Perioperative results of 214 laparoscopic adrenalectomies by anterior transperitoneal approach. Surg Endosc. 2008;22(2):522-6 doi: 10.1007/s00464-007-9555-7.

5. Walz MK, Alesina PF, Wenger FA, Deligiannis A, Szuczik E, Petersenn S, et al. Posterior retroperitoneoscopic adrenalectomy: results of 560 procedures in 520 patients. Surgery. 2006;140(6):943-8; doi: 10.1016/j. surg.2006.07.039.

6. Barczyński M, Konturek A, Gołkowski F, Cichoń S, Huszno B, Peitgen $\mathrm{K}$, et al. Posterior retroperitoneoscopic adrenalectomy: a comparison between the initial experience in the invention phase and introductory phase of the new surgical technique. World J Surg. 2007;31(1):65-71; doi: 10.1007/s00268-006-0083-8.

7 Myles PS, Myles DB, Galagher W, Boyd D, Chew C, MacDonald N, et al. Measuring acute postoperative pain using the visual analog scale: the minimal clinically important difference and patient acceptable symptom state. Br J Anaesth. 2017;118(3):424-9 doi: 10.1093/bja/aew466.

Надійшла 16.01.19 